\title{
Reconstructing Local Representatives Budgeting Function: Development Planning and Budgeting in Decentralized Indonesia
}

\author{
Naswar ${ }^{*} \quad$ Aminuddin Ilmar Achmad Ruslan Andi Pangerang Moenta \\ Faculty of Law, Hasanuddin University, South Sulawesi, Indonesia
}

\begin{abstract}
Several empirical studies reveal inconsistencies in planning and budgeting in many regions in Indonesia. Despite being the cause of inconsistencies, the budgetary authority of the local representative is unlikely to be abolished. It is reflected in the work of the local representatives in the area of budget allocation. The research is a normative legal research and supported by statutory and conceptual approaches; it is a reform-oriented research. The results show that the essence of the budget function of local representatives is supervision. Through this function, the local representatives supervise the determination of sources of regional revenue and expenditure in one year. It is carried out by discussing and approving or disapproving the draft proposed by the regional head. The local representative is still referred to as a controlling agency for regional budgeting and expenditure (control of budget). It is intended for the regional budget can truly be an instrument to realize community welfare through planning. Currently, the mechanism of budget discussion is long and complicated, making it difficult for local governments to maintain the consistency of plans in the budgeting process. The mechanism of discussion must be reconstructed in its concept as a way to maintain the consistency of budgeting decisions with planning.
\end{abstract}

Keywords: Budgeting; Decentralization; Local Government; Local Representatives

DOI: $10.7176 / \mathrm{JLPG} / 98-27$

Publication date:June 30th 2020

\section{Introduction}

Indonesia is a constitutional State. ${ }^{1}$ Law-based government will give the guarantee of people's basic rights protection so that the interest sides for the government that exercising State power and peoples as subjects of the State' proprietor can always be in accordance or in line. ${ }^{2}$ Therefore, the submission of the concept of the constitutional State as one of the legal foundations of governance plays a very important role not only as a corridor for government actions but also serves as a basic reference and benchmark for evaluating governance. In running these duties, the government is equipped with various authorities both attributive and delegative.

In Indonesia, the presence of provinces and regencies/cities is a juridical consequence of the implementation of the principle of decentralization in the Unity State of the Republic of Indonesia. The region exists as a public body (openbaar lichaam) and as a ruling organ (overheidsorganisatie) as a group of positions (ambtengroep) or referred to as local government. ${ }^{3}$ To realize these goals, adequate financial support is needed. In practice, the financial support in the form of a regional budget and set annually with regional regulations as a joint authority between the local representatives and the regional head.

In practice as happened so far, the legislative discusses the draft of national budget in detail up to the smallest unit (type of expenditure). This practice was corrected by the constitutional court by reducing the scope of the authority of the legislative to discuss and approve the draft of national budget only up to organizational units, functions, and programs. ${ }^{4}$ Meanwhile, the changes of the national budget due to circumstances that caused a budget shift had to be made, the constitutional court through this decision limited the authority of the legislative only in the shift of budget would increase or reduce the budget ceiling of ministries/institutions (organizations).

Actually, such decision by the constitutional court only corrected articles related to the authority of legislative in the budgeting process. But furthermore, this decision has a legal effect on the authority of the local representatives. This means that the authority of the local representatives to discuss and approve the draft of national budget is only detailed up to the organizational units, functions and programs.

As seen the extent of local representative's authority in the budgeting process. The local representatives can disclose and change the budget proposal prepared by the local government. It is also possible for the local representatives to turn away from the memorandum of understanding because it is deemed not to have binding

\footnotetext{
${ }^{1}$ Ilmar, A. (2014). Hukum Tata Pemerintahan. Prenadamedia. Jakarta. p. 37

${ }^{2}$ Aspan, Z., \& Yunus, A. (2019). The right to a good and healthy environment: Revitalizing green constitution. IOP Conference Series: Earth and Environmental Science, 343 (1): 012067.

${ }^{3}$ In Act No. 23 of 2014, the local government is interpreted simultaneously as an activity or activity of organizing government (in the dynamic sense) and the office environment, namely the regional head and local representatives (in the static sense) as the ruling organization (overheidsorganisatie) which is a group of positions (ambtengroep)

${ }^{4}$ The Constitutional Court's Decision No. 35/PUU-XI/2013 is a landmark decision, which reform the order of functions between State institutions in exercising the budget function. See Yunus and Reza Faraby, (2014). Reduksi Fungsi Anggaran DPR dalam Kerangka Checks and Balances, Jurnal Yudisial, Volume 7 No. 2: 199.
} 
legal force, so that during the discussion the draft of national budget tends to ignore the memorandum of understanding that has been prepared. By law, there are no rules requiring the local representatives to approve all material of the draft of national budget. In addition, there are no clear benchmarks or parameters to approve the draft of national budget or without changes. More important is result to agree collectively. Finally, the resulting regional budget ultimately more depends on the "accept and give" between the local representatives and the regional head that takes place during the process of joint discussion of the draft of regional budget concerned. In such circumstances, it may occur that the approved regional budget is inconsistent.

Several empirical studies reveal inconsistencies in planning and budgeting in many regions in Indonesia. This inconsistency occurs for several reasons, one of which is budgetary intervention of the local representatives is too strong. ${ }^{1}$ It is reflected in the work of the local representatives in the area of budget allocation. In the context of the discussion of the draft of national budget, this is referred to by Dian Puji N. Simatupang as a micro-technical or micro-practice discussion states that it would cause the legislative exist on the calculation of political transactions over budget figures with motivation beyond the rationality of the plan as earlier determined.2

An irony is that the involvement of the local representatives in the budgeting process causes inconsistencies in planning and budgeting. Despite being the cause of inconsistencies, the budgetary authority of the local representative is unlikely to be abolished. Based on the legal construction of the problems above, this paper will focus on discussing the reconstruction of the budget function of local representatives. This reconstruction will enable the budget function to be carried out properly and for maximum benefit for whole people.

\section{Method of Research}

The research is a normative legal research and supported by statutory and conceptual approaches. ${ }^{3}$ Statute approach is used to study, explore, and examine the legislation relating to the budget function of the local representatives. While, the conceptual approach is used to explores the function of budgeting in local government. This exploring is needed to distinguish the character of the budget function of the local representatives from the regional government. By distinguishing the character of their respective functions, it is expected that a legal argument will be built in answering the problem.

\section{Strengthening Local Representatives Budgeting and Accountability in Local Government}

Function of budgeting in local government cannot be separated from the concept of decentralization which requires that the administration of government is not solely carried out by the central government, but by lower selfgoverning units (zelfstandig). From the point of view of democracy, decentralization is an instrument of realizing public welfare. The presence of an autonomous government unit will bring government closer to the people so that the different interests of the people can be served appropriately. Local government is the main government unit to carry out the function of public welfare or social justice.

In general, the relationship between the central and local governments is reflected in intergovernmental fiscal relations. Delegation of tasks to local governments in autonomy must be accompanied by financial transfers (money follow functions). Delegation of expenditure (expenditure assignment) as a consequence of the granting of broad authority and public service responsibilities must be followed by the delegation of revenue (revenue assignment). Without this delegation, local autonomy becomes meaningless.

As mentioned above, it is clear that decentralization in the sense of handing over government affairs contains the distribution of financial power (related to revenue and expenditure). This is usually associated with the notion of devolution in the British or political decentralization in the United States, or staatskundige decentralisatie in the Dutch. Therefore, as determined by Article 283 paragraph (1) of Act No. 23 of 2014, the local financial management is an inseparable part of the implementation of Government Affairs which become the authority of the region as a result of the handing over government affairs.

Now, the problem is what the meaning of the power of local financial management? Planning of activities (planning) and budgeting are both a series of activities (cycles) of local financial management. Certainly, as the budgeting activities are part of the local financial management which is the domain (authority) of the regional head, ${ }^{4}$ the regional head is also the one who can be called as the regional budget compiler, not the local representatives. However, even though the function of budgeting is in the hands of regional heads, it does not mean

\footnotetext{
${ }^{1}$ See, Edy Marbyanto, Peta Permasalahan dalam Proses Perencanaan dan Penganggaran di Daerah, https://syukriy.wordpress.com, downloaded on 19 April 2017; Nursini, Perencanaan Pembangunan dan Penganggaran Daerah: Teori dan Aplikasi, http://repository.unhas.ac.id/handle/123456789/22397, downloaded on 20 April 2017; and Elizabeth Karlinda dkk, Optimalisasi Fiskal bagi Pertumbuhan Ekonomi Daerah: Peran Belanja Operasional dan Belanja Modal dalam APBD, https://www.kppod.org, downloaded on 21 April 2017.

2 Simatupang, D.P.N.'Mereposisi Hak Budget DPR', Harian Kompas, 18 June 2014, Jakarta

${ }_{3}^{3}$ Marzuki, P.M. Penelitian Hukum, (Jakarta: Kencana Predana Media Group, 2008), p. 35

${ }^{4}$ Article 284 paragraph (1) of Law Act No. 23 of 2014, "The regional head is the holder of regional financial management authority and represents the local government in the ownership of separated regional assets.
} 
that the process of drafting of regional budget is alienated, cannot be interfered by other institutions. In accordance with the theory of limitation of power, the authority of an institution is always limited by the authority of other institutions. The process of drafting the regional budget always involves the local representatives.

If examined exactly, there are several reasons that can be used to state that the local representatives are not the compiler of the regional budget. The first, the drafting of the regional budget is the authority of the regional head. Only the regional head has the right to prepare the draft of regional budget. The local representative does not have the right to take the initiative to prepare and submit a draft of regional budget. Therefore, the regional head sets and ratifies it. The second, the involvement of the local representatives in the process of drafting the APBD or that the DPRD budget function in the form of authority to discuss is not a drafting function of the regional budget. Likewise, the discussion of the draft of regional budget was also intended to reach agreement. The agreement is a decision. In fact, not reaching an agreement can still be called a decision. Both in a positive and fictitious sense in which not reach an agreement (inconclusive), at the last stage the regional head decides the budgeting decision.

If consistent to the ideas as determined above, then the budget function of the local representatives in the form of the authority to discuss can be said to be only evaluative and corrective, namely in order to ensure consistency of planning and budgeting. Seeing from the function of government administration (State administration), the drafting of the regional budget is essentially included in the besturent function both in terms of managing and administering. Therefore, the regional budget is besturende product. From another point of view, because the regional budget is stipulated in a local regulation whose contents are binding to the public, the regional budget can also be called a regelende product (regulation). The problem is whether it can be concluded that the local representatives are the drafter of the regional budget through the function of establishing a regional regulation?

Drafting the regional budget is an exclusive authority of the regional head. Therefore, only the regional head has the right to use the right of initiative to prepare the draft of regional budget. The local representative does not have the authority to prepare the draft of regional budget. Therefore, the local representatives cannot also be a drafter of the regional budget through the function of establishing a regional regulation.

\section{Basic Essence of the Meaning of Budget Function by Local Representative}

As the regional heads, the local representatives are also an element of regional administration. In such a position, they also carry out government functions (State administration), one of which is the budget function. From the perspective of a parliamentary institution, the budget function is usually equalized with budgetary rights. Bagir Manan interpreted this right as the right to participate in determining the budget. ${ }^{1}$ The meaning of "determine" here is that the local representatives discusses and approves (or disapproves) the budget plan, according to which Jimly Asshiddiqie said it was an endorsement or material determination. ${ }^{2}$ That is, the budget plan can be said to be final. It was said that the preparation of the material had been completed, because basically it could no longer be changed, except in the context of perfection based on the evaluation results by the Minister of Home Affairs or governor. If so, what exactly is the essence of local representatives' approval of the budget plan?

In the concept of absolute monarchy, the power of State administration is concentrated in the hands of the king (or what is referred to other terms), including the power of budget management. Quoting P. Alons' opinion, Arifin P. Soeria Atmadja argued that in the field of budget management, ${ }^{3}$ the king acted as the maker, executor and at the same time the supervisor of the State budget he made. ${ }^{4}$ Even if there are other institutions outside the king, it is only apparatus of the king, established by the king for the sake of their authority, especially to accompany and provide advice in carrying out various State activities. In Britain, for example, such institution is called Privy Council. In France, a similar advisory body was originally called Conseil du Roi (the predecessor of Conseil d'Etat). Likewise, in the Dutch is Raad van State.

However, after the revolution which succeeded in limiting the power of the king, the function of the advisory body was reduced, and its role was replaced by a representative body which later became known as parliament. This transfer of functions not only reflects the parliament's victory over the king, but also marks the beginning of the era of popular sovereignty. As a result of the revolution, parliament was made a representation of the people. Although legally, all power exists or comes from the king's power, so it is known for example "King or Queen in

\footnotetext{
${ }^{1}$ Bagir Manan, DPR, DPD dan MPR dalam UUD 1945 Baru, (Yogyakarta: FH-UII Press, 2003), p. 34

2 Jimly Asshiddiqie's opinion was expressed when outlining the legal meaning of the approval of the draft bill by the plenary session of the parliament. For more, see Jimly Asshiddiqie, Perihal Undang-Undang di Indonesia, (Jakarta; Secretariat General and Registrar of the Indonesian Constitutional Court, 2006), pp. 291-298.

${ }^{3}$ The term "budget management" is used in Act No. 17 of 2003, by the term "fiscal management". Said by Arifin P. Soeriaatmadja et al, fiscal management includes policies and activities related to the national budget management from the preparation of the draft of national budget policy, drafting, determining, implementing, supervising and the accountability of national budget. See Arifin P. Soeriaatmadja et al, Kompendium Bidang Hukum Keuangan Negara (Sumber-sumber Keuangan Negara)', Final Report, National Legal Development Agency, Ministry of Law and Human Rights R.I, Jakarta, 2010, p. 10

${ }^{4}$ See again footnote No. 39
} 
Parliament" which shows that parliament is apparatus of the king, parliament is seen as a representative of the sovereign people. In fact, in its development, the king let his power be exercised in full and autonomous by the parliament. With this position and its name, parliament functions to channel the aspirations, interests and opinions of the people.

Such development, it can be said that the principle of democracy or popular sovereignty is not only related to the parliamentary institution but also the institution of the president. This consistency is an ideal form to realize the goals of regional development, which is also the goal of local government. Planning includes the formulation of plans and ways to realize them later in a budgeting document. Therefore, budgeting decision-making should be based on the rationality of the planning documents that have been made. In essence, the scope of local representatives' authority to discuss RKUA, RPPAS, and RAPBD is limited, as seen in Chart 1.

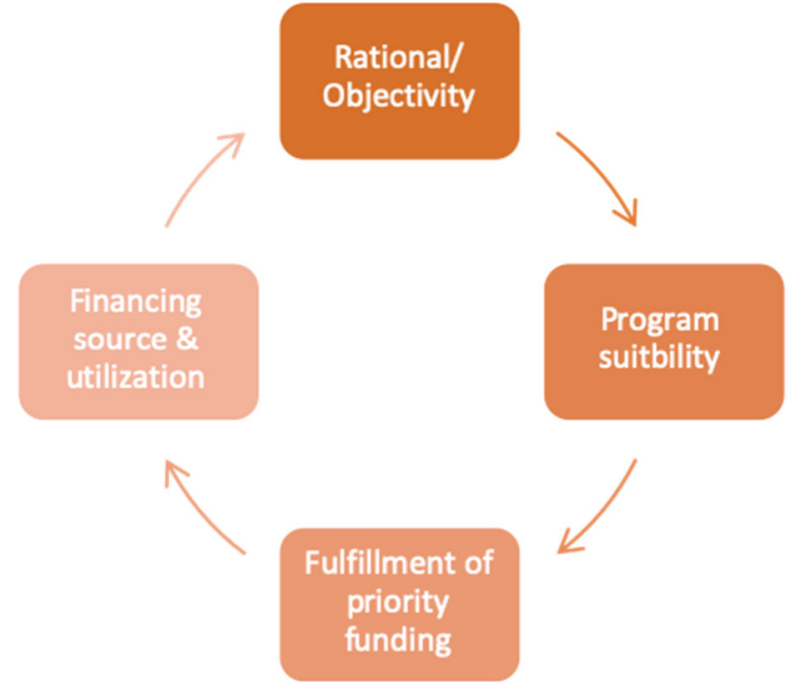

Chart 1. Scope of local representatives' authority in discussion

The first is the rationality of income projections based on objectified basis of calculation. The second is the suitability of programs and activities. The third is the fulfillment of funding for development priorities, including for the education function, health budget, and infrastructure; and the fourth is the source and utilization of financing to cover deficits and finance financing expenditures that are the regional obligation.

The understanding that the budget must follow the plan still applies, even though new activities are possible. According to author, the addition of new activities is another form or variation of planning adjustments. That is, the addition of new activities is "addendum" or adjustment of what has been stipulated in the previous RKPD based on the circumstances referred to in Article 343 paragraph (2) and (3). If the local government cannot show the situation as intended, it means that the local government has no right to propose the addition of new activities. Automatically, the local representatives will not (must) agree on such a proposal.

With such understanding, the discussion of the budget will be seen as an effort to maintain budget discipline based on the discipline of the previously determined plan. ${ }^{1}$ Related with programs and activities, budget discussion becomes a process of escorting programs and activities from the planning process into the budgeting process. Not the mechanism of "inclusion" of new activities at a glance or "advanced mindset" as practiced so far. However, if the scope of the budget discussion is limited only to the program level, while the activities in the RPPAS are apparently not consistent with those in the RKPD, does the local representatives just let the inconsistency occur? In accordance with the nature of the budget function of the local representatives as oversight, the local representative institution must be able to correct it. This means that the activity must be included in the scope of the budget discussion by the local representatives. ${ }^{2}$

The scope of authority is clearly broader than the scope of the discussion of budget allocations by the legislatives. Based on the provisions of Article 98 of Act No. 17 of 2014, the local representatives was represented by the commission to discuss and determine budget allocations for the functions and programs of ministries/institutions, the results were submitted to budgeting body for synchronization. The results of the synchronization were then refined again in the commission and then returned to the budgeting body for the final material for the determination of the national budget. This provision is in line with the constitutional court' decision to reduce the authority of the legislative to discuss the allocation details only to the program level. In the decision

\footnotetext{
${ }^{1}$ Heller, P., Harilal, K. N., \& Chaudhuri, S. (2007). Building local democracy: Evaluating the impact of decentralization in Kerala, India. World development, 35(4), 626-648.

${ }^{2}$ Such discussions are also reflected in the budgeting of multi-year activities. These activities are activities that are budgeted for one year or more
} 
referred to, the constitutional court gave legal considerations as follows:

... detailed discussion up to the activities level and type of expenditure (unit three) in the national budget is the implementation of program for planning as the authority of the President, because the implementation of the budget details is closely related to the situation and conditions and socio-economic dynamics at the time the plan is implemented. When the local representatives through budgeting body has the authority to discuss the draft of regional budget in detail up to the level of activity and type of expenditure, at that time the legislative has passed its authority in carrying out the budget function and has gone too far into the implementation of budget planning which is the domain of executive power.

Thus, the domain of legislative' authority discusses the details of allocation, starting from the thought that the activities and types of expenditure are the domain (authority) of the President which should not be interfered by the legislative. If consistent with the idea above, the legislative should not discuss the program. Isn't the executive prepares the program? Therefore, it is also strange that the legislative only has the authority to discuss the details of allocations to organizational units, functions and programs.

Actually, the reduction of the legislative' authority is based more on pragmatic considerations. If based on the principle of specialty, the national budget as approved by the legislative must be detailed. However, as Siswo Sujanto said, due to various constrains, especially time and competency, ${ }^{1}$ a detailed budget discussion is something that the legislative cannot do.

Meanwhile, in terms of quantity, all expenditure allocation comes from the amount of mandatory and binding indirect expenditure (component of reducing the real capacity of regional finance) plus the amount of nondiscretionary and discretionary direct expenditure as well as the amount of discretionary indirect expenditure (allocation of real regional financial capacity as priority order). ${ }^{2}$ The allocation of real region financial capacity has taken into account the financing policy to be carried out to balance the surplus/deficit and net financing (balanced budget or SILPA with zero balance) according to the logic of preparing the regional budget posture (taxspending hypothesis or the amount of revenue target will determine the expenditure estimation), where priority I gets first priority before priority II. Priority III gets budget allocation after priority I and II met their funding needs.

Therefore, programs that provide great benefits to the people will get main priority in the budget allocation, and then it is followed by the budget allocation for programs with a lower weight. Conversely, if there is efficiency (savings) on the budget, programs that have a weight that gives lower benefits to the people must be saved first (cut). ${ }^{3}$ In principle, not all government functions are funded, if it does not provide greater benefits to the people, then it does not need to be funded.

As the logic of preparing the regional budget posture, the discussion of the amount of expenditure is carried out simultaneously with the discussion of revenue projection and financing revenue. It means that the changes in the revenue budget and financing revenue will cause changes in the budget and/or financing expenditure. In the case of a change in revenue targets, a temporary budget ceiling is adjusted to anticipate possible changes in sources and use of financing, as the logic of tax spending hypothesis.

Certainly, before the decision to change the temporary ceiling is taken, an agreement is needed first in the local representatives. ${ }^{4}$ From the perspective of the parliamentary institution, in Jesse Burkhead's idea, agreement is authorization, or machtiging in D. Simons' idea, which is interpreted as granting power from parliament as a sovereign representation of the people. ${ }^{5}$ That is, the agreement is a "constitutive requirement" as basis of the authority of the local government to correct the temporary budget ceiling. Without these requirements, local governments are not authorized to change expenditure estimates. Based on this provision, the local representatives also have the right to propose new expenditure allocations to obtain mutual agreement. The local representatives ought to serve to maintain and guarantee the consistency of planning and budgeting, ultimately trapped into inconsistency.

\section{Conclusion}

The essence of the budget function of local representatives is supervision. Through this function, the local representatives supervise the determination of sources of regional revenue and expenditure in one year. It is carried out by discussing and approving or disapproving the draft proposed by the regional head. The mention of the budget function as a separate function does not cause the position of the local representatives to be the drafter of the regional budget. The local representative is still referred to as a controlling agency for regional budgeting and

\footnotetext{
${ }^{1}$ That was stated by Siswo Sujanto when giving expert testimony of the testing of Act No. 27 of 2009 and Act No. 17 of 2003.

${ }^{2}$ The order of priorities does not indicate the order of the percentage amount but rather for the purposes of ordering the fulfillment of funding needs.

${ }^{3}$ Kurniawan H., 'Money Follow Function dan Money Follow Program', Warta Anggaran, Directorate General of Budget, Ministry of Finance of the Republic of Indonesia, Thirty Edition - 2016, p. 10.

${ }^{4}$ Junaenah, I. (2016). Moral and Political Accountability of Local Representatives Body in Indonesia. In International Conference on Ethics in Governance (ICONEG 2016). Atlantis Press.

${ }^{5}$ Soeriaatmadja et al, (2010). Op. Cit., p. 219
} 
expenditure (control of budget). It is intended for the regional budget can truly be an instrument to realize community welfare through planning. Currently, the mechanism of budget discussion is long and complicated, making it difficult for local governments to maintain the consistency of plans in the budgeting process. The mechanism of discussion must be reconstructed in its concept as a way to maintain the consistency of budgeting decisions with planning. Based on the concept, the improvement of the mechanism of budget discussion is done by unify the discussion of RKUA, RPPAS, and RAPBD in one meeting.

\section{References}

Aspan, Z., \& Yunus, A. (2019). The right to a good and healthy environment: Revitalizing green constitution. IOP Conference Series: Earth and Environmental Science, 343 (1): 012067.

Asshiddiqie, J. (2006). Perihal Undang-Undang di Indonesia, Jakarta; Secretariat General and Registrar of the Indonesian Constitutional Court.

Heller, P., Harilal, K. N., \& Chaudhuri, S. (2007). Building local democracy: Evaluating the impact of decentralization in Kerala, India. World development, 35(4), 626-648.

Ilmar, A. (2014). Hukum Tata Pemerintahan. Prenadamedia. Jakarta.

Junaenah, I. (2016). Moral and Political Accountability of Local Representatives Body in Indonesia. In International Conference on Ethics in Governance (ICONEG 2016). Atlantis Press.

Kurniawan, H. (2016). 'Money Follow Function dan Money Follow Program', Warta Anggaran, Directorate General of Budget, Ministry of Finance of the Republic of Indonesia, Thirty Edition.

Manan, B. (2003). DPR, DPD dan MPR dalam UUD 1945 Baru, Yogyakarta: FH-UII Press.

Marzuki, P.M. (2008). Penelitian Hukum, Jakarta: Kencana Predana Media Group.

Razak, A. (2005). Kedudukan dan Fungsi Peraturan Kebijakan di Bidang Perizinan dalam Rangka Penyelenggaraan Pemerintahan. (Dissertation). Post-graduate, Hasanuddin University.

Simatupang, D.P.N. 'Mereposisi Hak Budget DPR', Harian Kompas, 18 June 2014.

Soeriaatmadja A. P. et al, (2010). Kompendium Bidang Hukum Keuangan Negara (Sumber-sumber Keuangan Negara)', Final Report, National Legal Development Agency, Ministry of Law and Human Rights R.I, Jakarta.

Yunus, Y., and Faraby, R. (2014). Reduksi Fungsi Anggaran DPR dalam Kerangka Checks and Balances, Jurnal Yudisial, Volume 7 No. 2: 199. 